\title{
Extending the Americas paleoclimate transect through the Antarctic Peninsula to the Pole
}

\section{Dominic Hodgson, E. Wolff, R. Mulvaney and C. Allen}

British Antarctic Survey, Cambridge, UK; daho@pcmail.nerc-bas.ac.uk

If we are to trust models used to predict future climate change, we need to be assured that they can reproduce the spatial and temporal pattern of natural climate variability. PAGES recognized this by setting up the PEP (Pole-Equator-Pole) transects, which aimed to determine the climate, especially throughout the Holocene, along continental transects. However, the PEPs end in mid-latitudes in the southern hemisphere and have not been integrated with the records available from the Antarctic continent. The Antarctic Peninsula (AP) bridges that gap and is particularly important, being one of the three fastest-warming regions on Earth $\left(3.4^{\circ} \mathrm{C} /\right.$ century) (Vaughan et al., 2003). The rate of temperature increase is more than five times the global mean $\left(0.6 \pm 0.2^{\circ} \mathrm{C}\right)$ during the 20th century, leading to shifts in species distribution, catastrophic disintegration of ice shelves, retreat and accelerated discharge of continental glaciers (Cook et al., 2005; Pritchard and Vaughan, 2007). The British Antarctic Survey (BAS) project "Climate and Chemistry-PEP" (CACHE-PEP) and University of Ghent project "Holocene climate variability and ecosystem change in coastal East and Maritime Antarctica" (HOLANT) are seeking to place the Last Glacial Maximum (LGM) through Holocene variability of AP and Antarctic climate in the context of global variability, as a contribution to understanding the significance of recent changes. It is doing this by extending the PEP-I (Americas) transect through the AP. A program of collaborative fieldwork collecting ice cores, marine and lake sediment core data, is already well underway (Fig. 1).

In 2005, the BAS drilling of a new 948-m-deep ice core to bedrock was completed on Berkner Island at the southern end of the Atlantic conveyor in the Weddell Sea, together with French partners at the Laboratoire de Glaciologie et Géophysique de I'Environnement. Initial results show that the Antarctic ice sheet in the Weddell Sea region was likely to have been thinner at the LGM than ice sheet models suggest, and that it may not have been over-ridden by the main Antarctic ice sheet, calling for a re-think about the volume of the Antarctic ice sheet in this sector of Antarctica during the last glacial period. Preliminary temperature records from the ice core suggest relative stability throughout the Holocene. Building on

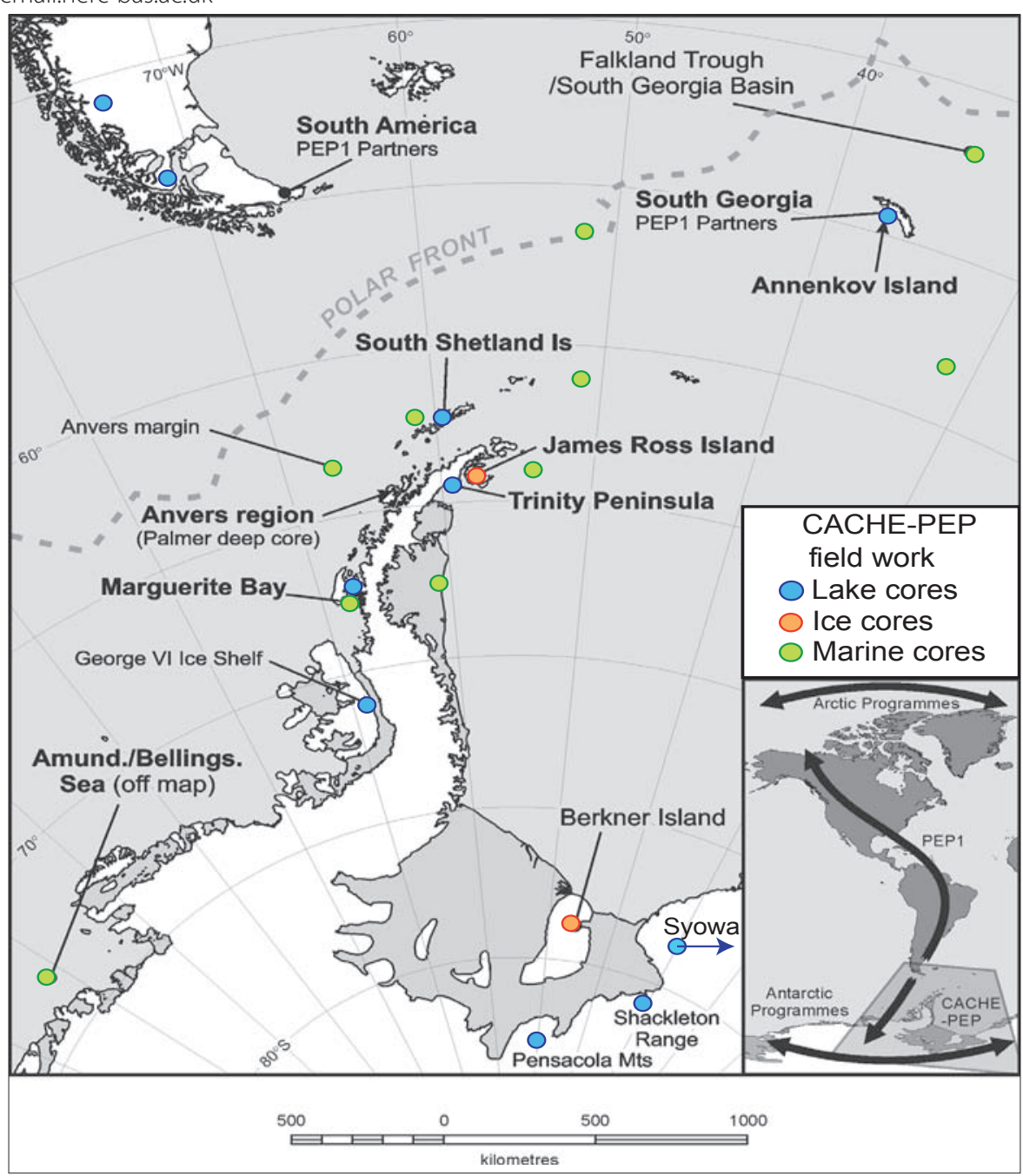

Figure 1: The region of focus, including all core types and locations.

the Berkner Island record, we are now in the advanced stages of logistics planning to drill a further ice core from James Ross Island at the northern end of the Antarctic Peninsula. Radar profiling suggests that this site will contain a 400 m column of ice that is likely to produce the longest Holocene record from the northern AP. Drilling to bedrock on James Ross Island will put the AP ice core records of the past few centuries into the perspective of the full Holocene climate record and allow us to state, in combination with lake records, whether the recent warming is unusual, or is similar to previous trends when the record over centennial timescales is taken into account. The timing of AP warm periods can then, for the first time, be compared with ice-shelf break-up in the same geographical region and with other climate and environmental changes along the extended PEP transect.

Lake and marine sediment records are also being collected to examine how the Holocene record in the ice cores is re- lated to changes in terrestrial and marine environments along the AP transect. Lake sediment cores collected from Tierra del Fuego (with collaborators), South Georgia, the South Shetland Islands, Marguerite Bay, Alexander Island and the TransAntarctic Mountains have been selected to span the latitudinal transect. These are being used to provide records of ice-shelf break-up, deglaciation, and temperaturerelated variables such as changes in primary production and moisture balance. Already, we have shown from ice-dammed lakes that the largest ice shelf on the west of the Antarctic Peninsula, George VI Ice Shelf, retreated in the early Holocene, c. 9.6-7.73 kyr BP. This retreat immediately post-dates the early Holocene climatic optimum recorded in several continental ice cores from Antarctica and coincides with an influx of warmer ocean water onto the western AP shelf at 9 cal kyr BP (Smith et al., 2007). The collapse of a currently extant ice shelf immediately after the early Holocene climatic optimum implies that 
early Holocene atmospheric and ocean temperatures in the AP region were higher than those measured in recent decades. However, if IPCC predictions of increased atmospheric temperatures in the coming decades continue to apply to the AP we can expect that its ice shelves will continue to retreat (Hodgson et al., 2006).

Marine sediment cores collected from the northeast of South Georgia, the Scotia Sea and down both sides of the AP are also revealing spatial and temporal changes in oceanographic variables along the AP transect. Initial results, focussing on changes in sea-ice extent, suggest an early retreat of summer sea ice across the Scotia Sea, with the average summer sea-ice margin being close to its Holocene position before $21 \mathrm{cal}$ kyr BP. In contrast, the winter sea-ice limit was stable north of the Falkland Trough until at least $19 \mathrm{cal}$ kyr BP (Allen et al., 2005). This is similar to records from the eastern Atlantic and Indian sectors of the Southern Ocean that also document a pre-LGM summer sea-ice maximum and early retreat to a near-modern extent by the LGM (Crosta et al., 1998; Gersonde et al., 2005). This means that the seasonal area of sea-ice growth and decay would have been more than double that of today's Southern Ocean, producing a much larger expanse of seasonally open-water than most models suggest. The associated impacts on Southern Hemisphere albedo and ocean-atmosphere energy transfers would have had a profound influence on feedback-dynamics during the glacial transition and are being further explored.

Our ice, lake and marine records have been selected for their high resolution and to facilitate detailed time-series analyses to determine the timing and phasing of climate events through the Holocene. Our activities also compliment a recent intensification of paleoecological research in southernmost South America and to the new and exciting ice core records from central East Antarctica (produced) and West Antarcica (in progress). Together with records from collaborating groups, these activities should give us a comprehensive view of how the climate system in the AP has behaved, and how it is linked to global climate via $\mathrm{CO}_{2}$, orbital forcing, major modes of atmospheric circulation, ocean circulation and sea ice.

Further information: www.antarctica.ac.uk/bas_ research/current_programmes/cache.php www.holant.ugent.be/

Selected links:

www-lgge.ujf-grenoble.fr/

www.hamilton.edu/news/exp/antarctica/2004/ faculty.html

http://shaldril.rice.edu/

www.salsa.uni-bremen.de/

www.pages-igbp.org/science/initiatives/lotredsa/

\section{References}

Allen, C. S., Pike, J., Pudsey, C. J. and Leventer, A., 2005: Submillennial variations in ocean conditions during deglaciation based on diatom assemblages from the southwest Atlantic, Paleoceanography, 20: PA2012 10.1029/2004PA001055.

Hodgson, D. A., Bentley, M. J., Roberts, S. J., Smith, J. A., Sugden, D. E. and Domack, E. W., 2006: Examining Holocene stability of Antarctic Peninsula Ice Shelves, Eos Transactions, American Geophysical Union, 87: 305-312.

Smith, J. A., Bentley, M. J., Hodgson, D. A., Roberts, S. J., Leng, M. J., Lloyd, J. M., Barrett, M. J., Bryant, C. and Sugden, D. E., 2007: Oceanic and atmospheric forcing of early Holocene ice shelf retreat, George VI Ice Shelf, Antarctica Peninsula, Quaternary Science Reviews, 26: 500-516.

Vaughan, D. G., Marshall, G., Connolley, W. M., Parkinson, C., Mulvaney, R., Hodgson, D. A., King, J. C., Pudsey, C. J., Turner, J. and Wolff, E., 2003: Recent rapid regional climate warming on the Antarctic Peninsula, Climatic Change, 60: 243-274.

\section{The Lake Malawi Scientific Drilling Project}

\section{Christopher A. Scholz}

Department of Earth Sciences, Syracuse University, USA; cascholz@syr.edu

In 2005, an international team of researchers undertook an ambitious plan to drill two sites in Lake Malawi $\left(9^{\circ}-14^{\circ} \mathrm{S}\right)$, in water depths of 592 and $359 \mathrm{~m}$ in the central and northern basins of the lake. Lake Malawi is located in the southern end of the western branch of the East African Rift System (Fig. 1, inset). It extends along more than $550 \mathrm{~km}$ of the rift valley, and with a depth of $700 \mathrm{~m}$, it is the second-deepest lake in Africa. Along with Lake Tanganyika, Lake Malawi contains one of the longest highresolution paleoclimate records of the continental tropics.

The primary objective was to obtain a continuous, high-resolution (annualdecadal) record of past climates in the continental tropics, and to then determine if tropical African climate responded to changes in low-latitude precessional insolation (23-19 kyr), or to high-latitude ice volume (100 kyr and $41 \mathrm{kyr}$ ) forcing, during the late Pleistocene.

The project initially faced very difficult engineering and logistical challenges. A $160 \mathrm{ft}$ fuel barge was used as the drilling platform, which was stabilized by a portable dynamic positioning system designed to maintain the position of the barge for weeks at a time (Fig. 1). The drilling operation involved 26 personnel aboard the

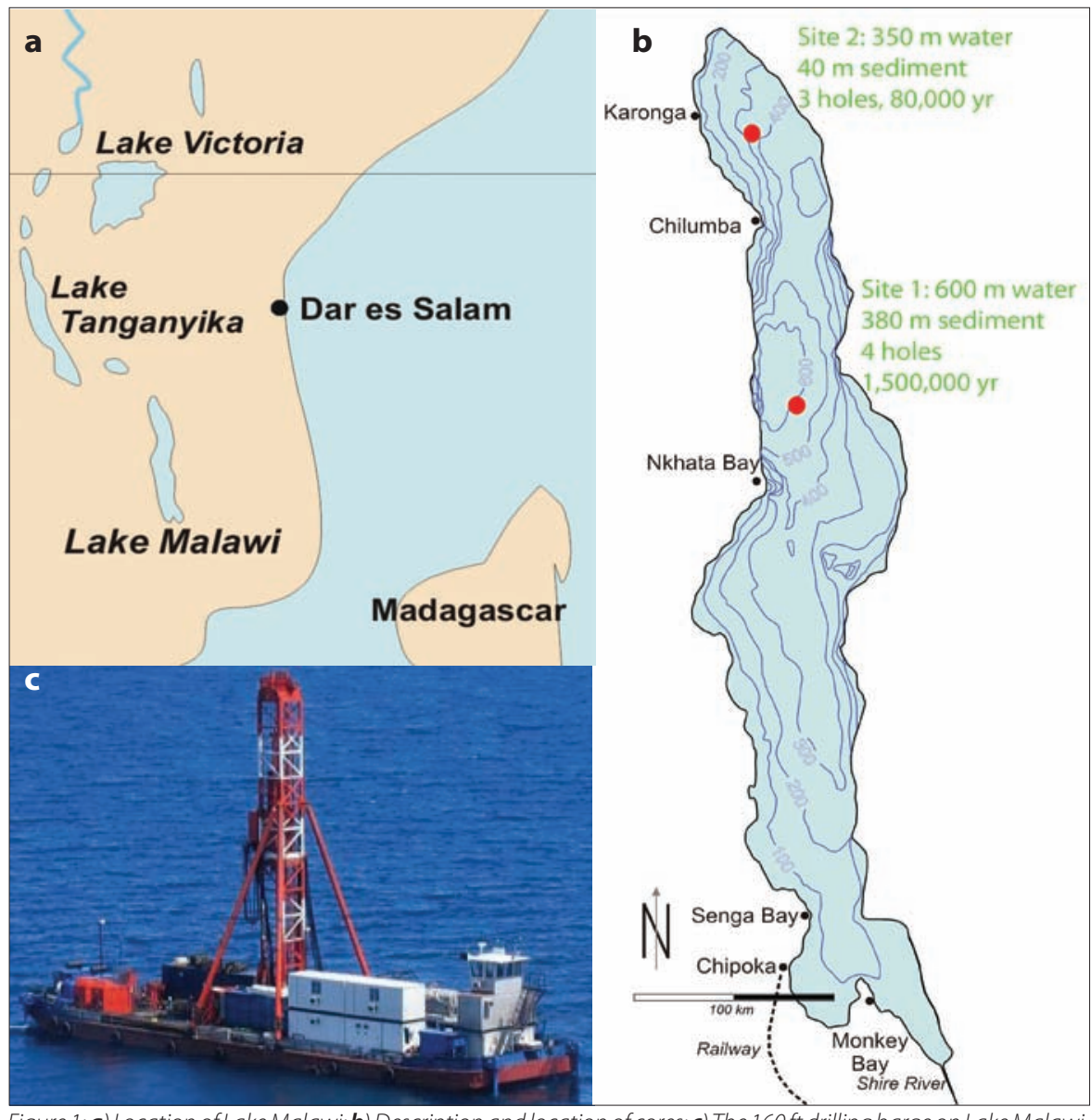

Figure 1:a) Location of Lake Malawi; b) Description and location of cores; $\mathbf{c})$ The $160 \mathrm{ft}$ drilling barge on Lake Malawi, where 26 members of the drill team, science team and ships crew lived for six weeks in 2005. Image courtesy of 1. Castaneda, University of Minnesota. 